
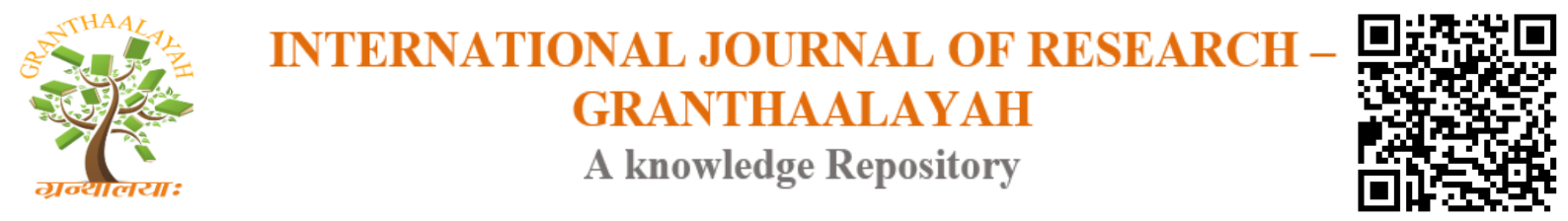

Science

\title{
FUNCTION, FORM, AND MEANING OF RITUAL AND MARKET IN HISTORICAL SITE OF KAMPUNG LUAR BATANG, JAKARTA, INDONESIA
}

\author{
Ashadi $^{* 1}$, Anisa ${ }^{2}$, Ratna Dewi Nur'aini ${ }^{3}$ \\ ${ }^{* 1,2,3}$ Department of Architecture, Universitas Muhammadiyah Jakarta, Indonesia
}

\begin{abstract}
Functions or activities that occur on a historic site did by a community will affect the formation of its physical environment. This research observes the ritual and market activities did by the community in the historic site of Kampung Luar Batang, North Jakarta, and sees its influence on the formation of its physical environment. The purpose of this research is to explore the meaning of ritual and market in historic site of Kampung Luar Batang, by relating the function or activity of ritual and market with the formation of its physical environment. The research method used is descriptive qualitative interpretative method. The observed function or activity is a pilgrimage ritual activity in the historic mosque building and market activity around the mosque. The form of physical environment observed is the spaces used as places of pilgrimage and market. The conclusion of this research is the function or activity of pilgrimage ritual and market did by the community of Kampung Luar Batang, North Jakarta, has a meaning of survival strategy in the modern city environment of Jakarta.
\end{abstract}

Keywords: Form; Function; Market; Meaning; Ritual.

Cite This Article: Ashadi, Anisa, and Ratna Dewi Nur'aini. (2017). "FUNCTION, FORM, AND MEANING OF RITUAL AND MARKET IN HISTORICAL SITE OF KAMPUNG LUAR BATANG, JAKARTA, INDONESIA." International Journal of Research Granthaalayah, 5(10), 246-255. https://doi.org/10.29121/granthaalayah.v5.i10.2017.2301.

\section{Introduction}

Function, form, and meaning are important elements of architecture. In the period of modern architecture, the so-called function was the activities performed by man in a three-dimensional space $[1,2]$. Container in the form of three-dimensional space that accommodated the activities was called the form. The meaning has three levels, ie levels of functional meaning, symbolic meaning or conceptual meaning, and existential or ontological meaning [3]. In this study, what is meant by the function is all the activities undertaken by the community of Kampung Luar Batang, North Jakarta, and what is meant by the form is the spaces that accommodate all these activities. The meaning can be understood from the result of the relation between function and form. 
The historic site of Kampung Luar Batang, North Jakarta, can not be seen as the same as the other kampung sites in Jakarta because there is historical values contained in it. Similarly, activities that occur in the site. The existence of the sacred tomb of Habib Husein and its site that was originally part of the old city of Batavia, known from the 18th century to the present. [Fig. 1].

Kampung Luar Batang is part of the territory of Kelurahan Penjaringan, Kecamatan Penjaringan, North Jakarta. Kampung Luar Batang has an area of approximately 131,500 m2, and adjacent to the old Fish Market area (now known as Kampung Akuarium) which has an area of about 34,505 m2. Administratively, Kampung Luar Batang consists of 36 RT and 3 RW. [Fig. 2]. In Kampung Luar Batang there is a historic mosque and the sacred tomb of Habib Husain bin Abu Bakar Alaydrus. This mosque is one of the historic old mosques, whose existence coincided with the birth of the city of Batavia or Jakarta. The uniqueness of the mosque that is located just at the mouth of the port of Sunda Kelapa, an important port in the past. The mosque is visited by many visitors not only from various regions in Indonesia, but also from Malaysia, Singapore and Brunei Darussalam.

The origin of Kampung Luar Batang's name has two versions. The first version relates to the ship's inland area during the Dutch East Indies. The second version deals with traditional stories about Habib Hussein's burial process.

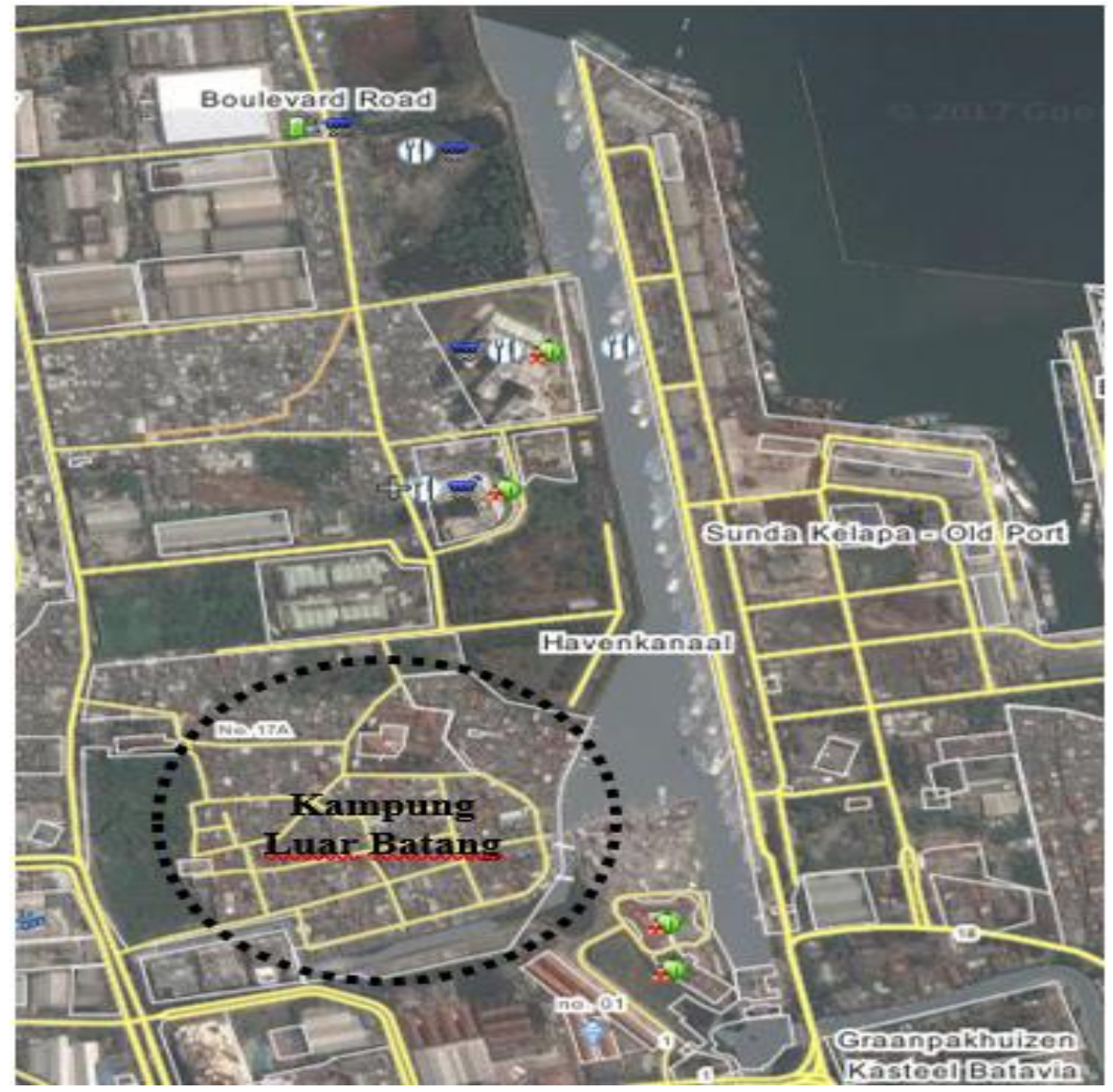

Figure 1: Location of Kampung Luar Batang 


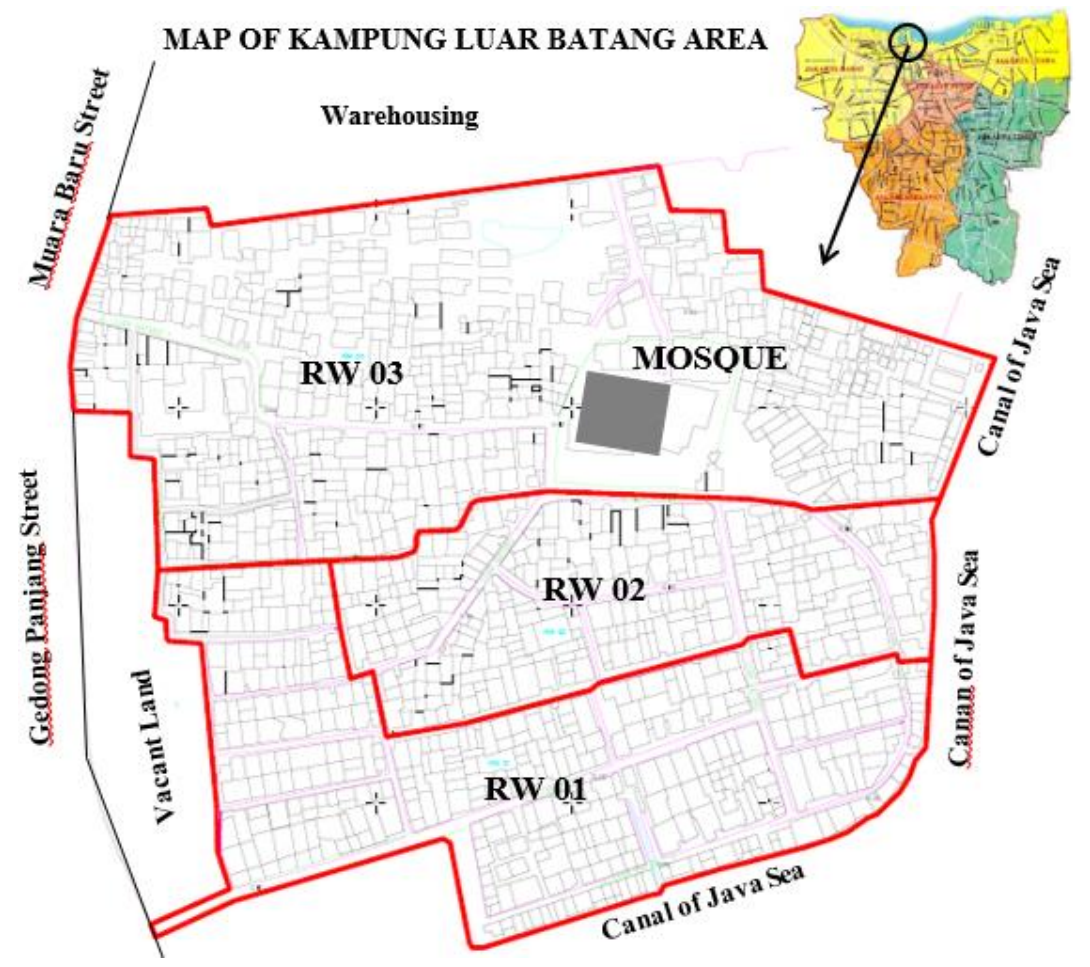

Figure 2: Map of Kampung Luar Batang Area

In the seventeenth century, after the Dutch East Indies founded the VOC, Kampung Luar Batang became temporary shelter for Nusantara sailors who would enter the Port of Sunda Kelapa. At the time, Dutch East Indies prohibited strictly the ships of Nusantara sailors through the port of Sunda Kelapa at night. Dutch East Indies did strictly supervision on all ships and cargo. They all had to pass the check point. While waiting to permit unloading at the port, sailors built temporary residences in the form of huts. Gradually, the settlement was known as Kampung Luar Batang, which meant a village outside check point $[4,5]$.

Another version of the origin of Kampung Luar Batang name came from the local myth about Habib Husein bin Abubakar Al-Aydrus who came to Batavia in 1736. Habib Husein died on June 27, 1756. His corpse was carried in a 'kurung batang' (brackets) and then stretched to a graveyard at Tanah Abang as usual. But when the corpse arrived at the cemetery, the body no longer existed and was already back to his home. This happens repeatedly. It was agreed that the corpse was buried in his house. It is therefore called 'Luar Batang'.

Since the VOC time, Dutch East Indies government often employed migrant labor to build the harbour and Batavia castle. Workers for those locations were transported from different places and were settled in Kampung Luar Batang. In the past, settlement of Kampung Luar Batang was segregated by ethnicities, resulting in the presence of Arabian cluster, Javanese cluster, and Bugis cluster. In 1631, there was a fish market in Kampung Luar Batang. The market was a floating market on the water at the river mouth, but due to the expansion of the Batavia castle in 1636 , the market was relocated to the west side of the river. [6, 7].

Kampung Luar Batang is a village that has historical value and is part of the old city of Jakarta. Kampung Luar Batang is protected by law to be preserved and gained conservation rights. The 
interesting thing is the site of Kampung Luar Batang currently lacks public space, so that the open space around the tomb and mosque is used for parking, social activity, and even the market.

This is the background of the need for research on the influence of the function or activity of Kampung Luar Batang community, North Jakarta, to form of the physical environment. Based on this background, this study aims to: [1] identify and know the functions or activities undertaken by the Kampung Luar Batang community; and [2] understand the meaning of ritual and market in the historic site of Kampung Luar batang through in-depth observation about the effect of function or activity of ritual and market activity on the form of its physical environment.

\section{Materials and Methods}

Kampung Luar Batang is a historic village centered on the mosque and sacred tomb of Habib Husein. This mosque and sacred tomb is often visited by pilgrims from various regions in Indonesia and even neighboring countries such as Malaysia, Brunei Darussalam and Singapore. The existence of mosque and sacred tomb is a major attraction visited by pilgrims and tourists.

The development of a region starts from a point that is considered important for the community such as mosques, sacred tombs, and markets. Kampung Luar Batang is growing based on the mosque built by Habib Hussein. The existence of the mosque became one of the attractions for Muslim sailors and traders who stop in Kampung Luar Batang and worship, and some even become santri and settled in Kampung Luar Batang. Since the early 1990s, this village began to be visited by immigrants from Central Java and East Java. As a village, Kampung Luar Batang meets the social and psychological needs of migrants generally from the region to accommodate the need for cheap and affordable homes. With the presence of these migrants, this village has attracted small and medium scale investors. This investor bought the land from the indigenous people of Kampung Luar Batang (especially the Betawi tribe) so that now the majority of Kampung Luar Batang population is from Java and a bit of the native population. [8].

Masjid Luar Batang consists of three parts, namely porch, main hall, and tomb. At the front of the mosque there is a court. To the west of the courtyard is a porch. To the west of the porch is the main room. To the south of the porch there is a tomb (cupola inside the enclosed room). For pilgrims, the porch is functioned for praying of women, before and after they make a pilgrimage to the grave of Habib Hussein, and the main room is functioned for praying of men.

The main function of Kampung Luar Batang Mosque is for the prayer. Additional functions that can be observed are functions related to ritual of pilgrimage activities. Open space and street adjacent to the mosque complex, became a function of the market.

In this research, to understand of function, form, and meaning of ritual and market in historic site of Kampung Luar batang, used approach of function-form-meaning relation in architecture.

Relation of function-form-meaning is one of the important themes in the study of architecture. Beginning by Marcus Vitruvius Pollio (circa 1st century BC), which stated that all buildings had to be built with reference to: durability (firmitas), convenience (utility), and beauty (venustas). Firmity can be defined as strength, utility as function, and venustas as aesthetics. Trium 
Vitruvius was later tested by David Smith Capon. Capon concluded that there were six categories in the principles of architecture, grouped into primary and secondary categories: function, form, meaning, as primary categories, and context, construction, spirit, as secondary categories. [9].

Purnama Salura and Bachtiar Fauzy developed the concept of function-form-meaning rotation. Each architectural design product should prioritize the elements of the function-form-meaning. The three elements form a triangular build, which is always in a state of change (spinning). In this concept shows that the architecture always changes. [10]. In this study, analysis and interpretation is done on the relations that occur in function, form, and meaning [Fig. 3].

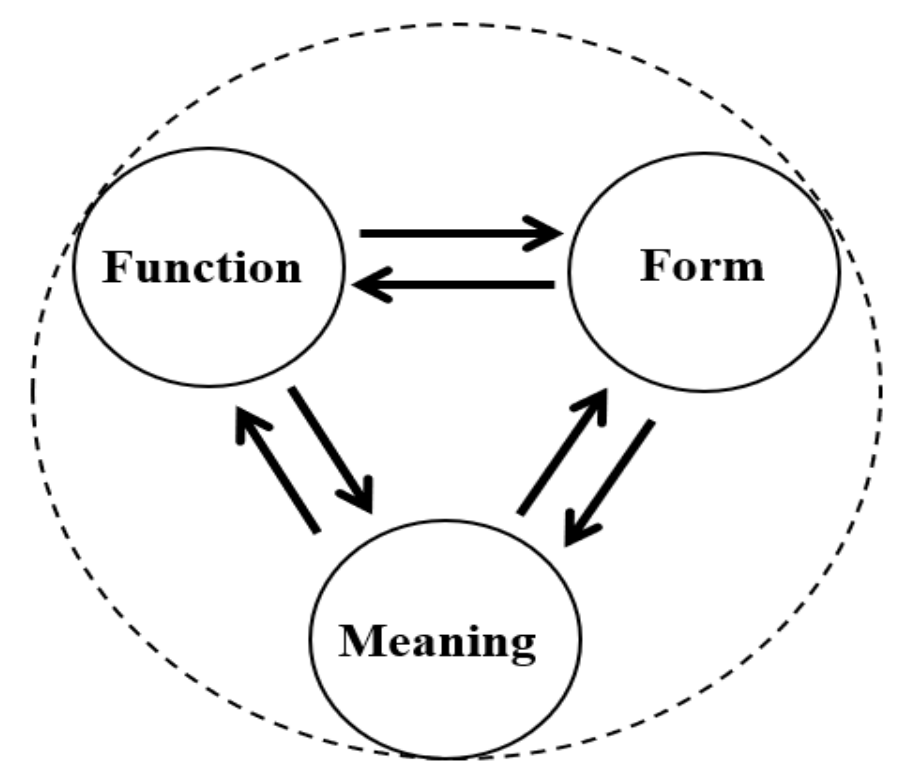

Figure 3: Relation of Function-Form-Meaning in Architecture

This research uses descriptive qualitative interpretative method. This method is applied to explore the meaning of ritual and market in the historic site of Kampung Luar batang through the following steps, which is built into a research framework [Fig. 4]:

1) Recording of ritual functions of tomb pilgrimage and market.

2) Recording forms of spaces as containers of functions or activities of pilgrimage rituals and market.

3) Description of the results of recording of ritual functions of tomb pilgrimage and market.

4) Description of the results of recording of forms as containers of functions or activities of pilgrimage rituals and market.

5) Analysis of the ritual functions of pilgrimage and the market to know and understand whether there is influence through careful observation of its relation to its physical environment.

6) Analysis of forms to know and understand whether there is influence through careful observation of its relation to the functions of the pilgrimage rituals and market.

7) Interpretation of steps number 5 and 6, to understand the meaning of rituals and markets in the historic site of Kampung Luar Batang. 


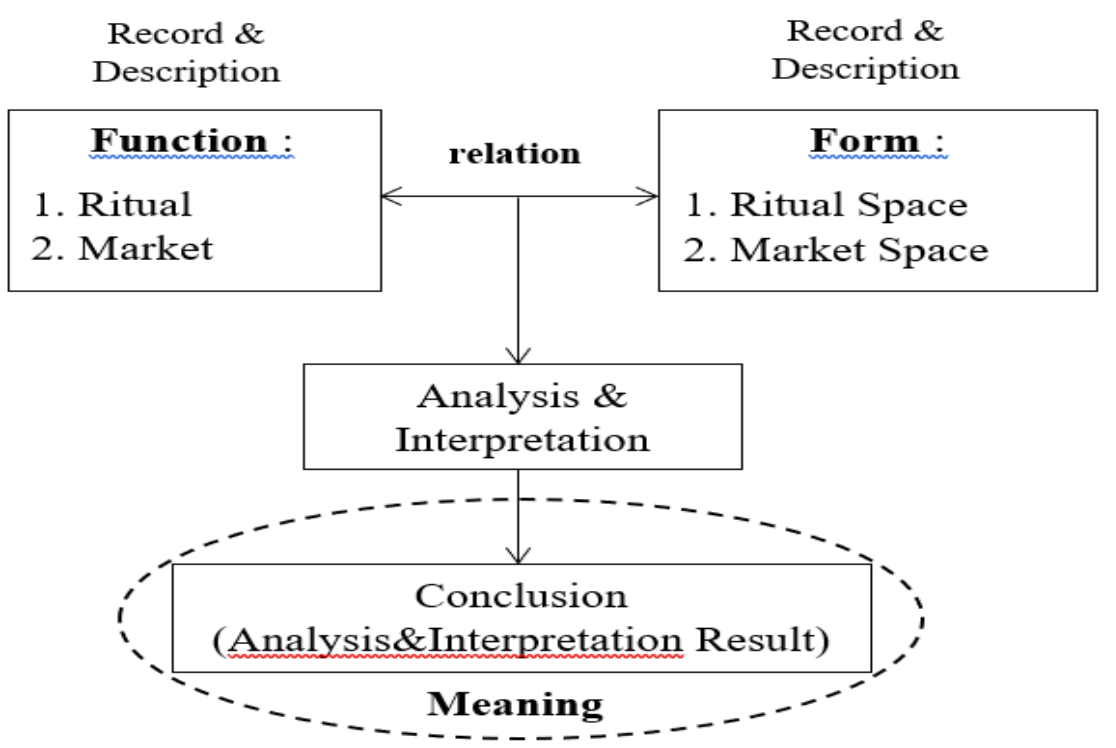

Figure 4: Diagram of the research framework

\section{Results and Discussions}

Pilgrimage activity to Habib Hussein's grave located next to the mosque's porch, each day involves a number of pilgrims ranging from 100 to 500 people. In general, pilgrims come from areas of Jadebotabek, Banten, and West Java. Pilgrimage activity on every Friday night has increased the number of pilgrims compared with ordinary days, which amounts to about 1000 3000 people. This pilgrimage activity started busy after praying of Ashar and reached its peak after praying of Isya.

In the commemoration of Habib Husein (haul:anniversary), visitors were about totaling 25,000 30,000 people. In general, people who come to bring with their family, and those who are members of the majelis taklim. Visitors not only meet the mosque complex (main hall, porch and courtyard) but also parking area and road segments especially close to the mosque.

Activity of Habib Husein haul commemoration started at 08:00 until praying of Dhuhur time. In the morning until about 10:00, in secretariat room of the mosque held terbangan and reading shalawat and history Habib Husein by a group of students (santri). This activity is conducted to accompany the guests of honor, such as the habib, kyiai, community leaders, and government leaders, who came and went straight into secretariat room. Visitors more and more and fill the entire room of mosque, courtyard, and road segments around the mosque. Around 10:00, the activity moved to the main hall of the mosque to accompany the honored guests, who also moved into the main room of the mosque. Not long afterwards, some habib and kyai gave lectures one after another. At that time the activity of terbangan stopped. By 12:00, the activity of haul was over and continued with the praying of Dhuhur in congregation. When praying of Dhuhur time arrived, only about a quarter attend praying of Dhuhur in congregation, because the mosque complex is not sufficient to accommodate the entire congregation. In each haul activity, the pilgrims present will also visit the tomb of Habib Hussein [Fig. 5 and Fig. 6].

This pilgrimage activity is also encouraging the flourishing of other weekly activities ie market 
or bazaar held every Friday night. Shelves were prepared from the time after the praying of Ashar. The bazaar is open until morning and sells all kinds of goods. Participants in the bazaar were street vendors from various areas in Jakarta. Based on the exploration, it was found that the street vendors moved from one place to another. The street vendors come from Pasar Minggu, Senen, Tanah Abang, and Muara Angke. Their number reached 60\% of all Friday night market traders. The other $40 \%$ are local residents, Luar Batang village, which makes their home as a trading place. Each stall is charged Rp. 5,000 and the restribusi ranged from Rp. 10,000 - 25,000.

Almost all the goods are on the Friday night market, besides of course the impromptu food stalls. Goods such as clothing, hijab, gamis, shoes, watches, women accessories, coffeeah (head cover), woodworking tools, rings, agate, socks, and do not miss perfume, can be found at Friday night markets. [Fig. 7 and Fig. 8].

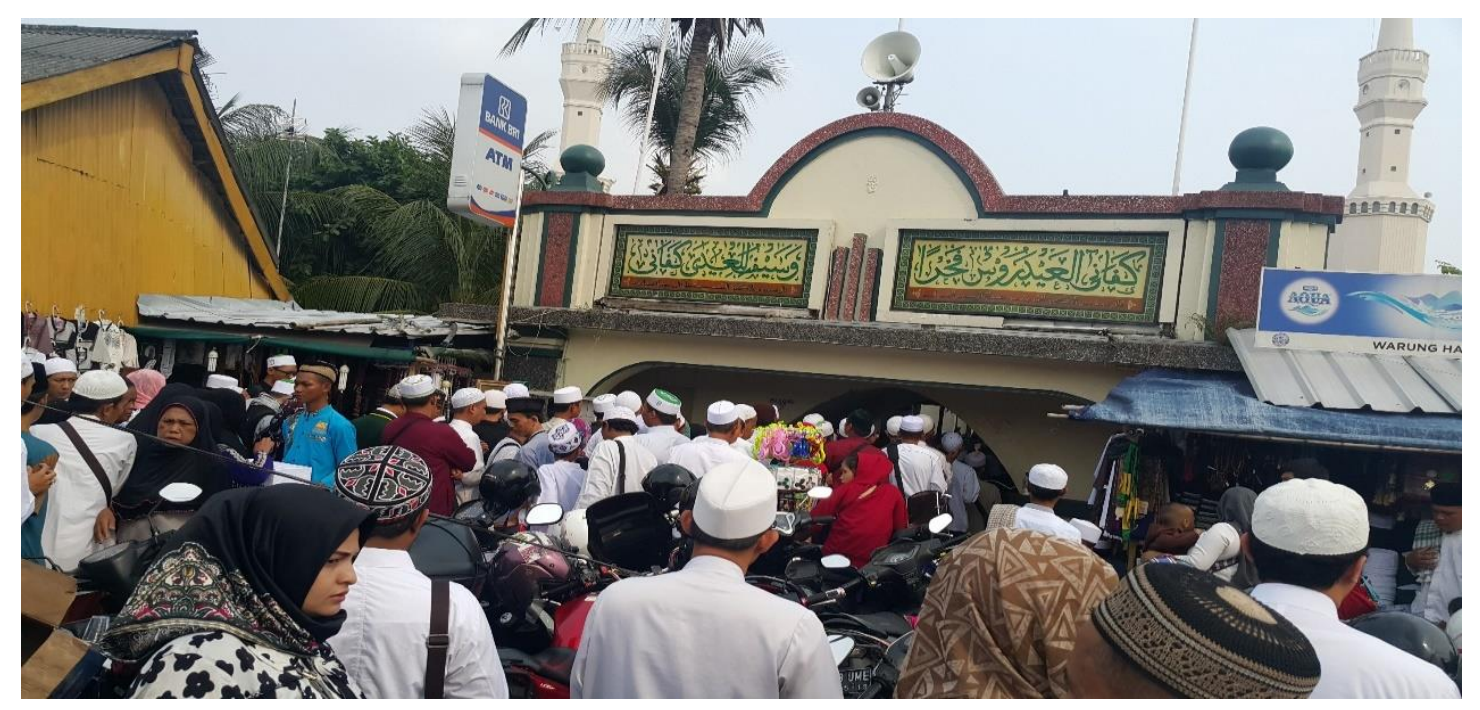

Figure 5: Visitors crowded the parking area in front of the mosque

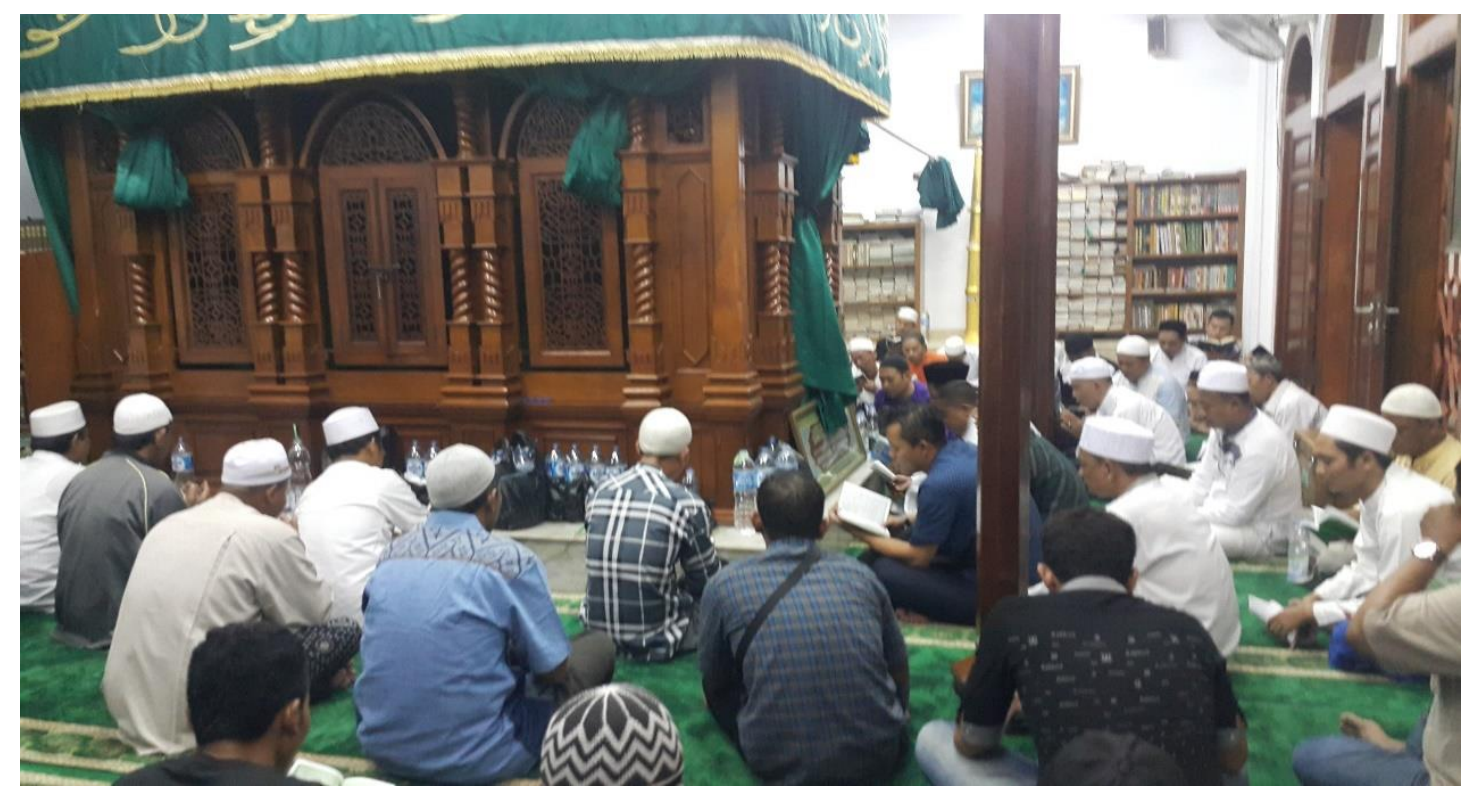

Figure 5: Visitors pray at the tomb of Habib Husein 


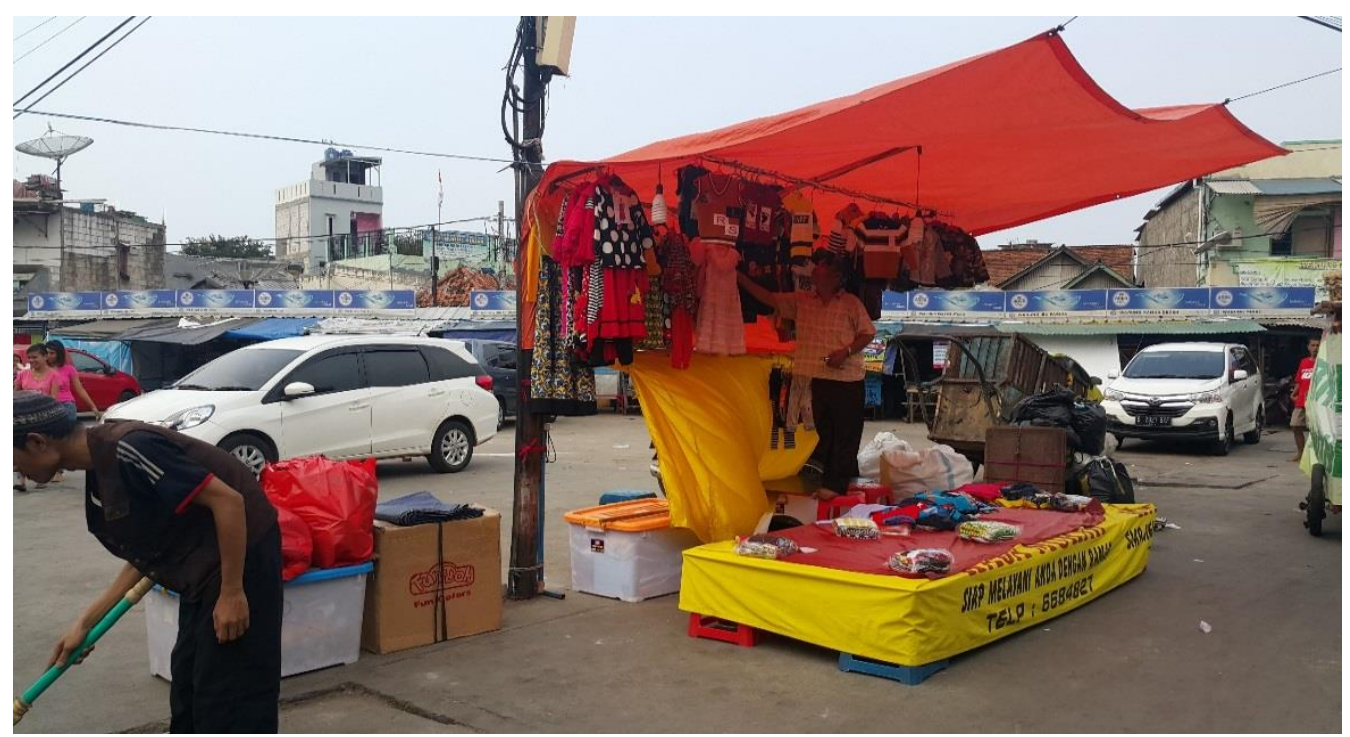

Figure 6: Street vendors began to prepare merchandise various types of clothing

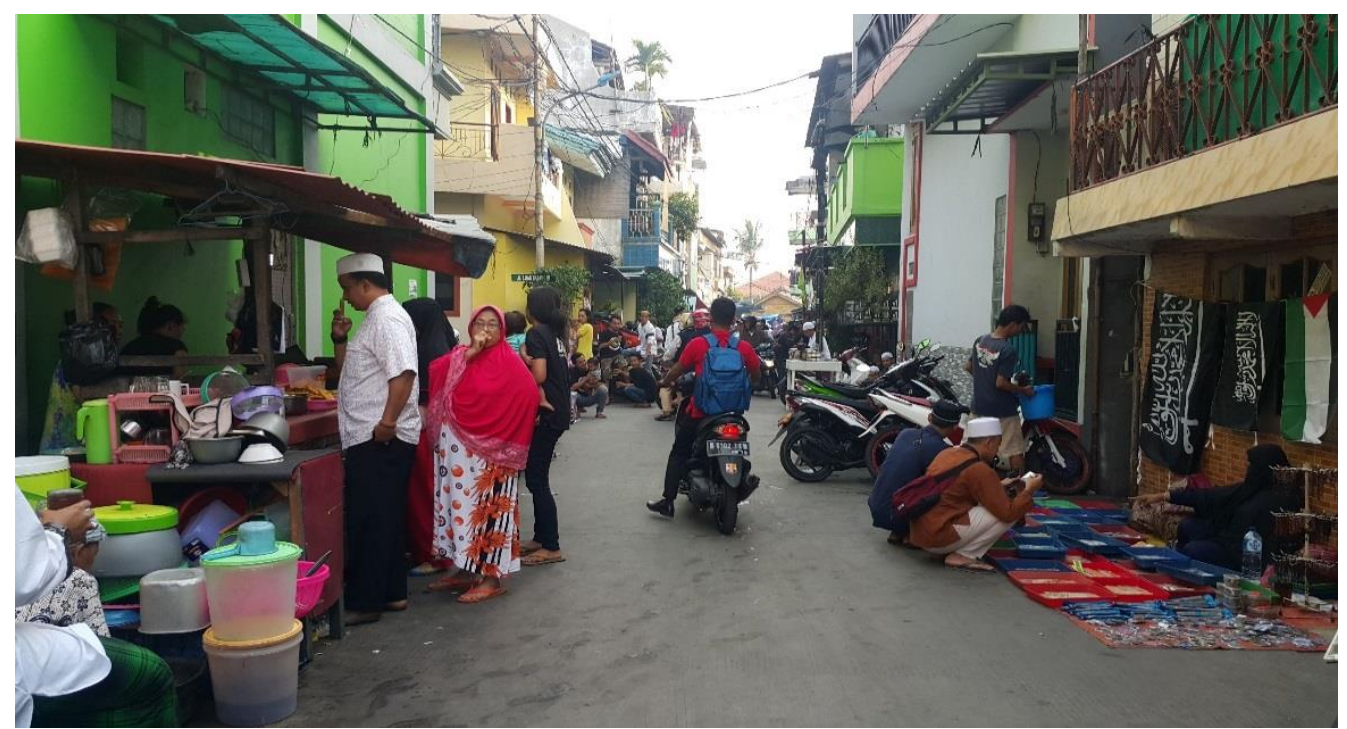

Figure 6: Street vendors began to prepare merchandise for various types of food and worship equipment

Friday night market occupies the area of Jalan Luar Batang 1 and 5, as well as part of Jalan Luar Batang 7. Out of the neighborhood streets in Kampung Luar Batang, there are only 4 wider streets, including Jalan Luar Batang 2. Because it is located some distance from the mosque complex, Jalan Luar Batang 2 is not used for the Friday night market. Crowded atmosphere seen on the road that is located close to the mosque. So it can be assumed that the night market activity is centered around the mosque.

Building elements in Kampung Luar Batang, especially which is close to the mosque, such as : fences, stairs and roofs located alongside the public roads, have additional functions. They are the place to display merchandise; drains covered with plywood are used to put the merchandise table; balconies between homes are used for mooring ropes to hung tents, so that the road can be covered. The covered road is used for buying and selling activities. [11]. 
Tomb of Habib Husein is the sacred maqom, non the sacred tomb as usual. Sacred maqom can be regarded as the magnet for several reasons: 1) it is located in the most strategic location physically and functionally; 2) according to the genealogy, Habib Husein bin Abubakar Alaydrus is the earliest saint of Islam in that region; 3) the sacred maqom area is a center for resident's activities. Maqom refers to the level degree of somebody's knowledge about Islam faith or someone who is considered as a close relative of the Prophet Muhammad. The pilgrimage is the central activity in the Kampung Luar Batang which has significant role in the increase of local economic activities. The strategic location of the Kampung to the centers of urban economic activities, in addition to the high intensity of pilgrimage, would in turn determine the population status. [12].

Ceremony of sacred ritual of Habib Husein haul held every year, which was lately more and showed increased activity aimed to maintain or renew order showed by safety and welfare of the community of Kampung Luar Batang. In this event, habib, kyai, and community leaders, confirmed their existence in the social and religious life of the community of Kampung Luar Batang. The idea of Habib Husein haul would continue to run along with the increasing role of them.

In this regard, Swanson said that if a group had the authority, that group was able to create the conditions to develop the concept of spirits [13]. The group who had the authority was habib, kyai, and community leaders. They were the actors who had the authority for producing and controlling the sacred place. As architecture, an actor is someone who has the power to create something and keep it [14]. Control is necessary before a group can shape the meaning of a place, or have a specific meaning or narrative widely accepted by others. In virtually all cases of highly contested religious sites, power is necessary to exert control. Power is the means to gaining possession of a site, or at least making claims to ownership rights, and is therefore a necessary component of this process. In fact, the production of sacred place is largely governed through power relations, which encompass processes such as domination and subordination, appropriation and dispossession, and the practice of exclusionary politics. [15].

Ritual activity of Habib Husein haul involving tens of thousands of visitors and led by the habib, kyai, and community leaders, which encourage the growth of market economic activities in Kampung Luar Batang can be understood as the efforts of those involved to maintain their respective status. This means that because of them, Kampung Luar Batang can survive in the modern city environment of Jakarta.

\section{Conclusions and Recommendations}

Function of ritual and market in historic site of Kampung Luar Batang, which could be seen through descriptive of making a pilgrimage to Habib Husein maqom and market especially the Friday night market, has a strong relationship with the form. The form is space which accommodates that function. That relationship can be interpreted as a form of strategy to survive the Kampung Luar Batang community in the modern city of Jakarta which is so fast development. 
The results of this study provide the following recommendations. The function of ritual and the market, and the physical form of the environment in the historic site of Kampung Luar Batang should be the attention of the leaders of Jakarta city administration because the people already feel able to survive in the rapid development of modern city of Jakarta.

\section{Acknowledgements}

This paper is part of a study with the title of 'Model Penataan Hunian di Sekitar Bangunan Bersejarah dalam Rangka Peningkatan Potensi Kawasan Wisata. Kasus Studi Hunian di Sekitar Masjid Luar Batang' with funding from DRPM with Decree of 'Direktur Jenderal Penguatan Riset dan Pengembangan 'No. 01 / E3 / KTP / 2017 dated January 6, 2017. Therefore, I thank Dr. Susilahati, as the Head of LPPM UMJ (Lembaga Penelitian dan Pengabdian Masyarakat Universitas Muhammadiyah Jakarta), who has assisted in the financing of this research.

\section{References}

[1] Adorno, Theodor W., Functionalism Today. Rethinking Architecture: A Reader in Cultural Theory. Leah, Neil (Ed.), London: Routledge; 1997, 6-19.

[2] Norberg-Schulz, Christian, Meaning in Western Architecture, New York: Rizolli; 1981, 186-187.

[3] Ghasemi, A., Taghinejad, M., Kabiri, A., dan Imani, M., Ricoeur's Theory of Interpretation: A Method for Understanding Text (Course Text), World Applied Sciences Journal, 2011, 15 (11), 1623-1629.

[4] Heuken, A., Historical Sites of Jakarta, Jakarta: Cipta Loka Caraka; 2007, 42 and 186.

[5] Puspitasari, Popi., Djunaedi, Achmad.,Sudaryono., Ahimsaputra, Heddy Shri., Cyclical Changes of Space: the Phenomena of Space Changes in Historic-Religious Kampung Luar Batang, Jakarta, Indonesia, Asian Journal of Environment-Behaviour Studies, Vol. 3, No. 9, July 2012, 33-46.

[6] Al-Qurtuby, Sumanto, Arabs and "Indo-Arabs" in Indonesia: Historical Dinamics, Social Relations and Contemporary Changes, IJAPS, Vol. 13, No. 2, 2017, 45-72.

[7] Funo, Shuji., Ferianto, Bambang F., Yamada, Kyouta, Considerations on Space Formation and Transformation of Kampung Luar Batang (Jakarta), Journal of Asian Architecture and Building Engineering/ May 2004/ 180, 173-180.

[8] Iskandaria, Harfa., Sumarno, Ispurwono., Silas, Johan., Peran Kampung Luar Batang Kecamatan Penjaringan Jakarta Utara Dalam Menunjang Konservasi Kota Tua, Arsitron Vol 4 No 1 Juni 2013, 1-7.

[9] Capon, David Smith., the Vitruvian Fallacy: Architectural Theory Volume One, New York: John Willey \& Sons; 1999, 179-194.

[10] Salura, Purnama., Fauzy, Bachtiar., The Ever Rotating Aspect of Function-Form-Meaning in Architecture, Journal of Basic and Applied Scientific Research, 2(7), 2012, 7086-7090.

[11] Padawangi, Rita. Irawati, Miya., Fatimah, Titin., Budi Theresia., Vernacular City Kota Tua: Cultural Identity in Everyday Urban Heritage, Final Report, Unesco, Jakarta, 2016, 89-99.

[12] Puspitasari, Popi. Djunaedi, Achmad.,Sudaryono., Ahimsaputra, Heddy Shri., Ritual and Space Structure: Pilgrimage and Space Use in Historical Urban Kampung Context of Luar Batang, Procedia-Social and Behavioral Sciences 36 (2012), 350-360.

[13] Swanson, Guy E., the Birth of the Gods, the University of Michigan Press, 1960, 26-27.

[14] Johnson, Paul-Alan., the Theory of Architecture, New York: Van Nostrand Reinhold; 1994, 269.

[15] Camhi, Natasha., The Manipulation of Sacred Places: The Role of Jerusalem's Temple Mount in The Construction of Identity. An Essay. Wesleyan University, 2012, 13-14.

*Corresponding author.

E-mail address: ashadi@ ftumj.ac.id 